\title{
RHEOLOGICAL PROPERTIES OF FEEDSTOCKS AND THE STRUCTURE OF INJECTION MOULDERS FOR SINTERING COMPOSITE TOOL MATERIALS BASED ON MMCS
}

\author{
REOLOŠKE LASTNOSTI MEŠANIC IN STRUKTURA \\ VBRIZGANIH REZKARJEV ZA SINTRANE KOMPOZITNE \\ ORODNE MATERIALE NA OSNOVI MMCS
}

\author{
Klaudiusz Gołombek $^{1}$, Grzegorz Matula ${ }^{1}$, Jarosław Mikuła ${ }^{1}$, Mirko Soković ${ }^{2}$ \\ ${ }^{1}$ Silesian University of Technology, Institute of Engineering Materials and Biomaterials, Gliwice, Poland \\ ${ }^{2}$ University of Ljubljana, Faculty of Mechanical Engineering, Ljubljana, Slovenia \\ klaudiusz.golombek@polsl.pl \\ Prejem rokopisa - received: 2015-10-20; sprejem za objavo - accepted for publication: 2015-12-24
}

doi: $10.17222 / \mathrm{mit} .2015 .318$

\begin{abstract}
New functional tool composite materials with a metallic matrix and reinforced with hard carbide phases have been developed The effect of the polymer binder has been determined for the used moulding a mixture of hard carbide powders based on WC, $\mathrm{TiC},(\mathrm{W}, \mathrm{Ti}) \mathrm{C}$, doped with $\mathrm{VC}, \mathrm{NbC}$ and/or TaC and powders of a metallic matrix in the form of Co and/or Ni. The relevant type of polymer binder was selected, its optimum volume fraction was determined, the rheological properties of the polymer-powder slip were investigated along with thermal debinding conditions, i.e., atmosphere, time and temperature, as well as solvent debinding conditions, i.e., solving time and temperature and sintering conditions were matched. The structure and mechanical properties of the produced tool materials were examined, especially their resistance to abrasive wear, hardness and bending strength.

Keywords: composite tool materials, reinforced metal matrix, powder injection moulding (PIM)
\end{abstract}

Razvili smo nove funkcionalne kompozitne orodne materiale s kovinsko matrico, ojačane s trdimi karbidnimi fazami. Določili smo učinek polimernega veziva, uporabljenega za brizganje zmesi trdih prahov, na osnovi WC, TiC in (W,Ti) C, legirane z VC, $\mathrm{NbC}$ in/ali TaC, ter prahov kovinske matrice v obliki Co in/ali Ni. Izbrali smo ustrezno vrsto polimernega veziva in določili njegov optimalen volumski delež. Raziskali smo tudi reološke lastnosti sistema polimer-prah skupaj s pogoji termičnega razpada veziva, (atmosfera, čas in temperatura), kot tudi pogoje razgradnje topil (čas in temperatura raztapljanja) usklajeno s pogoji sintranja. Določili smo strukturo in mehanske lastnosti izdelanih orodnih materialov, zlasti odpornost proti abrazivni obrabi, trdoto in upogibno trdnost.

Ključne besede: kompozitni orodni materiali, ojačana kovinska matica, oblikovanje prahov z vbrizgavanjem

\section{INTRODUCTION}

Research institutes active in the field of tool materials for many years have been endeavouring to develop a "perfect" tool material possessing high ductility, resistance to dynamic loads and high abrasive-wear resistance. The manufacturing costs of engineering materials would be markedly lower if such a tool, often coated with protective coatings, had been developed with cost savings associated with machining, especially manufacturing downtimes and the necessary replacement of a worn tool. Even the high costs of investigations of properties and applications of modern tool materials and the related manufacturing costs do not constitute a barrier for the development of this field of research.

The use of injection moulding or the extrusion of sintered tool materials represents one of the modern directions of the research. Powder forming and sintering technologies offer unlimited opportunities for selecting the chemical composition of the tool composites produced. Classical powder metallurgy based on uniaxial pressing and sintering with potential isostatic pressing at a high sintering temperature prevents the fabrication of tools with complicated shapes. The injection extrusion or forming techniques of a polymer-powder slip, undergoing rapid advancements, make it possible to produce relatively small parts with complicated shapes and a developed area, and also make it possible to produce materials not requiring plastic working or machining. The use of powder forming based on polymer binders, in particular injection moulding or extrusion, has become the subject of research in numerous research institutes and universities.

Moreover, our own research of high-speed steels manufactured by powder injection moulding and pressureless forming prove that the structure and wear resistance are similar with commercial high-speed steels, but with less ductility. In addition, the manufacturing technique employed, especially the debinding and sintering process carried out in protective atmospheres, permits the use of furnaces that are cheaper than vacuum furnaces, which is important in process lines. The monitoring and maintaining of a narrow range of sintering 
K. GOŁOMBEK et al.: RHEOLOGICAL PROPERTIES OF FEEDSTOCKS AND THE STRUCTURE ...

temperature is undoubtedly a difficult aspect in industrial conditions. The use of modern, polymer-binder-based powder-forming technologies, in particular injection moulding, for preparing metal-matrix-reinforced tool composites creates a promising outlook for the fabrication of functional materials. WC, (W,Ti)C carbides doped with $\mathrm{VC}, \mathrm{NbC}$ and/or $\mathrm{TaC}$, frequently used as hard reinforcing phases of sintered carbides based on cobalt, especially in this configuration, were used for fabricating composite tool materials, as TiC phases, mainly $\mathrm{VC}$, inhibit the growth of a WC carbide grain in sintering. Metal, constituting a matrix of sintered carbides, must exhibit a smaller affinity for carbon than a carbide metal, and in the liquid state it has to wet the carbide grains, interpenetrate the grains, filling in pores and exhibiting the limited solubility of carbide grains. Nickel and cobalt, often used as a matrix material, satisfy such conditions. ${ }^{1-22}$ Some research groups propose to use cheaper compounds for the metal matrix such as Fe, but the sintering of WC carbides with a steel matrix causes the dissolving of this type of carbides and the precipitation of $\mathrm{M}_{6} \mathrm{C}$ carbides with lower hardness.

The paper provides an overview of the fabricating of new Co- and/or Ni-based functional composite tool materials reinforced with hard carbide phases. The essence of the investigations concerns the application of a state-of-the-art polymer-powder slip forming technology for manufacturing composite tool materials in the form of sintered carbides ensuring high resistance to abrasive wear, corrosion and diffusion in the tools' working conditions.

\section{EXPERIMENTAL PART}

The experimental mixtures of powders used for manufacturing sintered carbides being the main component of the feedstock, as presented in Table $\mathbf{1}$ and in Figures 1 to 4 . The mixtures produced by Baildonit S.A. (CC1, CC2, CC3) come as a granulated product and feature a high flow rate and are intended mainly for

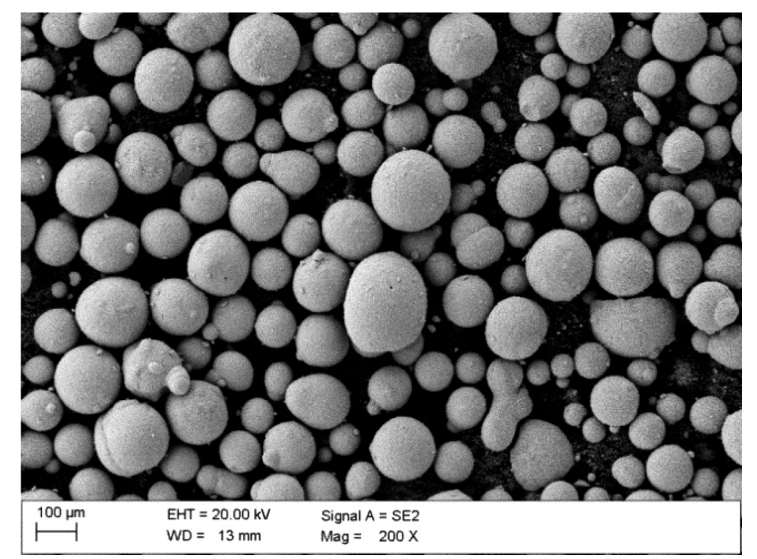

Figure 1: Morphology of $\mathrm{CC} 1$ granules

Slika 1: Morfologija CC1 granul
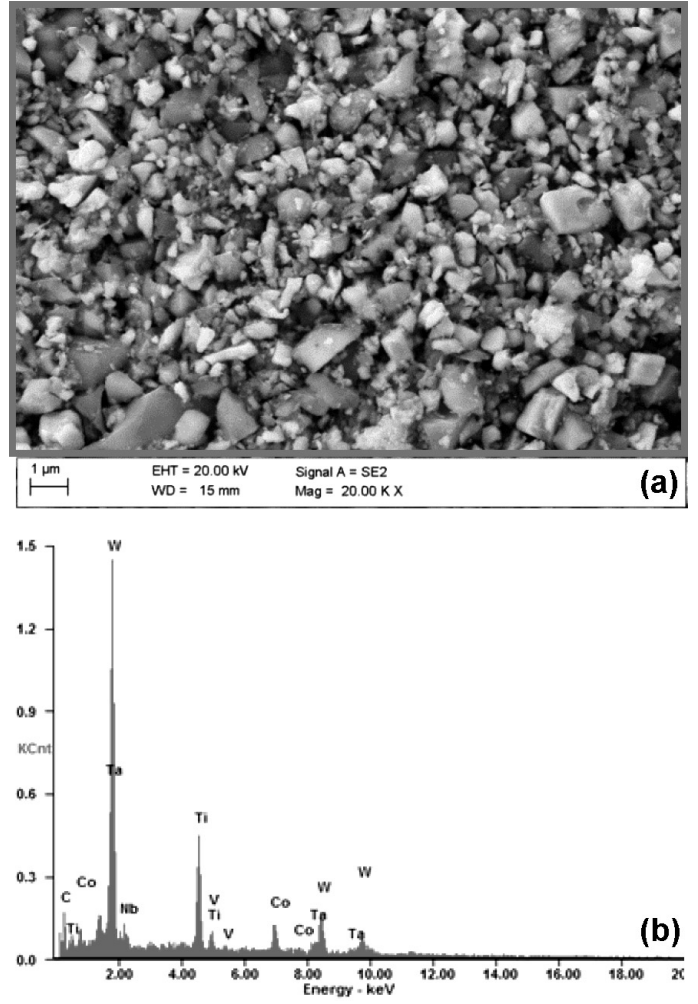

Figure 2: a) Morphology of $\mathrm{CC} 1$ powder, b) X-ray energy-dispersive plot of the area in Figure 2a

Slika 2: a) Morfologija prahu CC1, b) EDS-spekter področja označenega na Sliki 2a
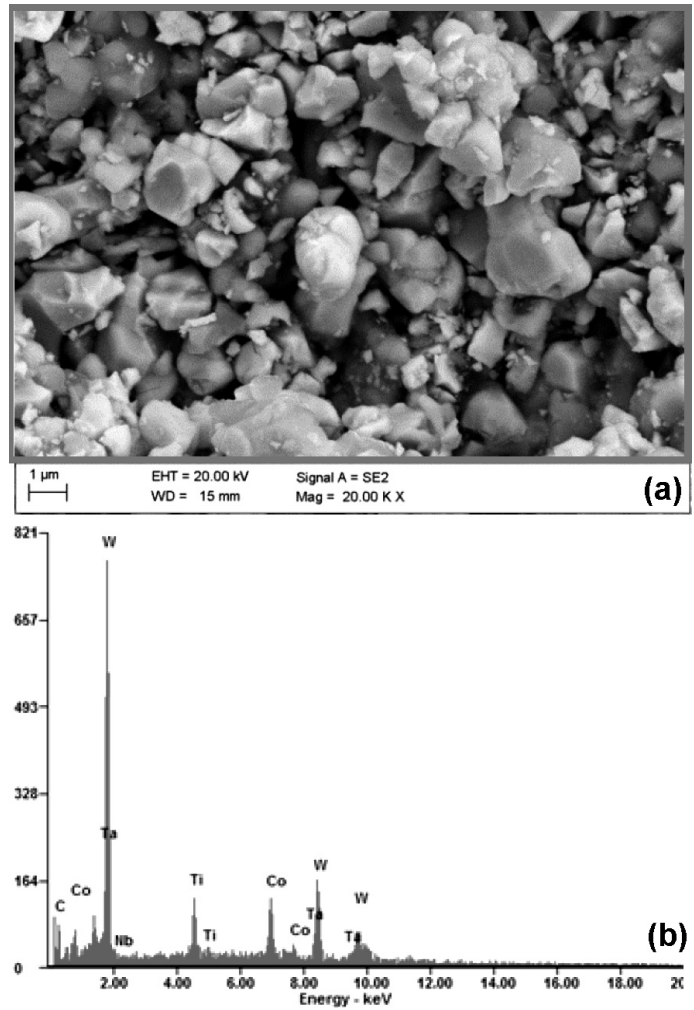

Figure 3: a) Morphology of $\mathrm{CC} 2$ powder, b) X-ray energy-dispersive plot of the area in Figure 3a

Slika 3: a) Morfologija prahu CC2, b) EDS-spekter področja označenega na Sliki 3a 

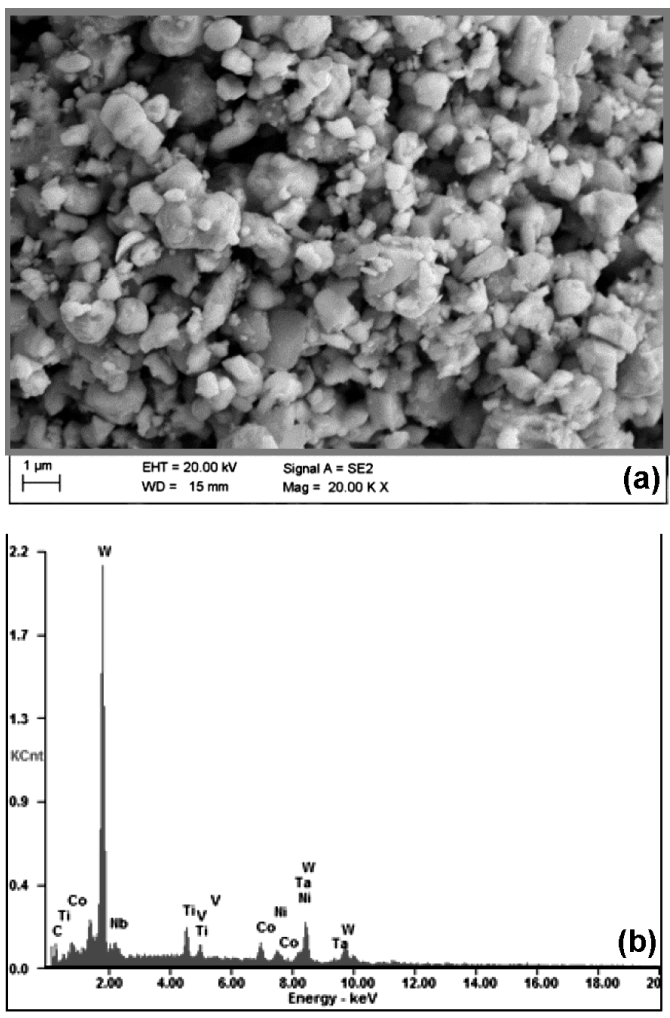

Figure 4: a) Morphology of $\mathrm{CC} 3$ powder, b) X-ray energy-dispersive plot the area in Figure 4a

Slika 4: a) Morfologija prahu $\mathrm{CC} 2$, b) EDS-spekter področja označenega na Sliki 4a

pressing shaped sections and then for sintering. The CC1, CC2, CC3 mixtures with a lubricant added exhibit the high compatibility required in moulding in a closed die. The mixture produced by Tetra Carbides-TC does not contain a lubricant.

Table 1: Applied mixture of carbides

Tabela 1: Uporabljena mešanica karbidov

\begin{tabular}{|c|c|c|}
\hline Designation & $\begin{array}{c}\text { Average } \\
\text { particle size }\end{array}$ & $\begin{array}{c}\text { Amount of components in } \\
\text { volume fractions, \% }\end{array}$ \\
\hline CC1 & $2-3 \mu \mathrm{m}$ & 57WC, 20TiC, 14Ta(Nb), $9 \mathrm{Co}$ \\
\hline CC2 & $2-3 \mu \mathrm{m}$ & $87 \mathrm{WC}, 5 \mathrm{TiC}, 8 \mathrm{Co}$ \\
\hline $\begin{array}{c}\text { TC Tetra } \\
\text { Carbides }\end{array}$ & $d_{50}=3.11 \mu \mathrm{m}$ & $\begin{array}{c}33 \mathrm{WC}, 33 \mathrm{TiC}, 25 \mathrm{TaC}, 8 \mathrm{NbC}, \\
\mathrm{Co}\end{array}$ \\
\hline $\mathrm{CC} 3$ & $1-2 \mu \mathrm{m}$ & $\begin{array}{r}\text { 69WC, 20 (TiC,TaC), 2VC, } \\
5 \mathrm{Co}, 4 \mathrm{Ni}\end{array}$ \\
\hline
\end{tabular}

The addition of a lubricant was considered when selecting a binder. Mixtures in the form of a granulated product make it possible to measure the powder grain size, hence only the average size of the powder grains given by the manufacturers is presented in Table $\mathbf{1}$. Grain size tests were made for the mixture of tetra carbides powders with a Malvern Mastersizer 2000 instrument for measuring the size of the particles with the laser-diffraction method.

A mixture of polypropylene (PP) and paraffin (PW) was used as a binder for producing the feedstock. The effect of the presence of stearic acid (SA), as a sur- factant, on the feedstock viscosity was also examined. The feedstock was prepared with the Rheomex CTW100p instrument by Haake shown in Figure 5 making it possible to record the torque of the vanes during the homogenisation of components. The fraction of the relevant components of the binder and powder is shown in Table 2. In order to cover the surface of the carbides with stearic acid (SA), carbide powders, stirred strongly for $30 \mathrm{~min}$ so that $\mathrm{SA}$ is distributed evenly across the surface of carbides, were added to the SA dissolved in ethanol. The mixture was then heated to $60{ }^{\circ} \mathrm{C}$ to evaporate the ethanol. The so-prepared carbide powders covered with the SA coating were next mixed with the main binder as PP and PW. Rheological tests were carried out in a capillary rheometer Rheoflixer by ThermoHaake at $170{ }^{\circ} \mathrm{C}, 180{ }^{\circ} \mathrm{C}$ and $190{ }^{\circ} \mathrm{C}$.

Table 2: Amount of components in all manufactured polymer-powder slurry in volume

Tabela 2: Volumski delež komponent v vseh proizvedenih kombinacijah gošče polimer-prah

\begin{tabular}{|c|c|c|c|c|}
\hline Designation & Powder & $\begin{array}{c}\text { PP, \% in } \\
\text { vol. frac. }\end{array}$ & $\begin{array}{c}\text { PW, \% in } \\
\text { vol. frac. }\end{array}$ & $\begin{array}{c}\text { SA, \% in } \\
\text { vol. frac. }\end{array}$ \\
\hline CC160SA4 & CC1 & 18 & 18 & 4 \\
\hline CC157SA2 & CC1 & 20,5 & 20,5 & 2 \\
\hline CC154SA0 & CC1 & 23 & 23 & 0 \\
\hline TC60SA4 & $\begin{array}{c}\text { Tetra } \\
\text { Carbides }\end{array}$ & 18 & 18 & 4 \\
\hline CC2 & CC2 & 18 & 18 & 4 \\
\hline CC3 & CC3 & 18 & 18 & 4 \\
\hline
\end{tabular}

In order to prepare a homogenous mixture with a low viscosity enabling injection moulding or extrusion, carbide powders were covered with a thin layer of stearic acid, thus increasing their wettability when mixing with other binder components and to decrease a ready feedstock's viscosity.

The coagulation speed of $10 \mathrm{~s}^{-1}$ to $10000 \mathrm{~s}^{-1}$ was chosen during the investigations and the length and width of the capillary is, respectively, $30 \mathrm{~mm}$ and $1 \mathrm{~mm}$. The melting point for the binders used was determined

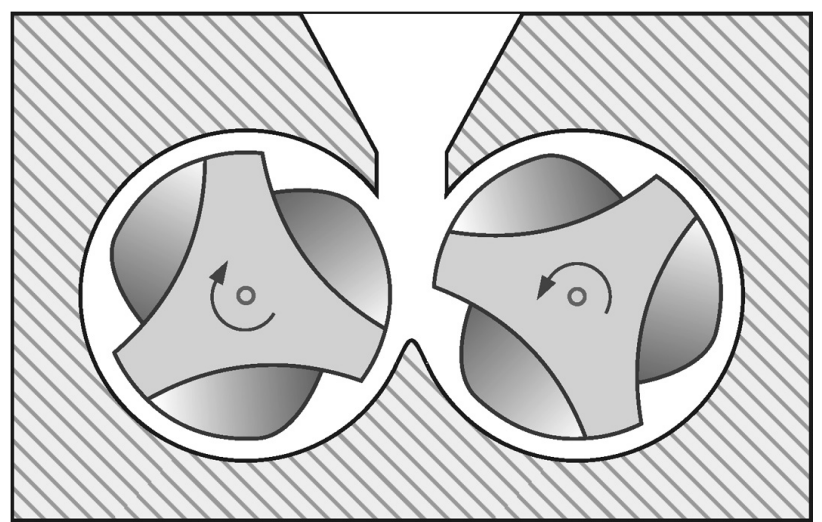

Figure 5: Scheme of Haake Rheomex CTW100p apparatus for the torque measurment and homogenization

Slika 5: Shema naprave Haake Rheomex CTW100p za merjenje navora in homogenizacijo 
with differential scanning calorimetry (DSC) using a Perkin Elmer instrument, Diamond model, in order to determine the extrusion or injection moulding temperature of the prepared polymer-powder mixtures. The amount of heat can be recorded with the instrument and its software, presented as a peak chart as a heat effect of the process curve, while the area of the field underneath the peak equals the enthalpy of such a transformation.

The AB Machinery AB-400 piston injection moulder with a retractable mould heated to $150{ }^{\circ} \mathrm{C}$ was used for the injection moulding. The extruded sections were produced in the Rheomex CTW100p twin-screw extruder.

The structural observations of the examined composite tool materials were made with a LEICA MEF4A light microscope with the light field technique and the morphology of the powder grains and the structure of the materials produced was viewed with a scanning electron microscope ZEISS SUPRA 35 at the accelerating voltage of $20 \mathrm{kV}$ using SE and BSE detection.

The bending strength of the injection moulders was measured with a ZWICK Z100 tensile testing machine fitted with an adapter for three-point bending. The test was made in line with PN ISO 3327: "Determination of bending strength".

\section{RESULTS AND DISCUSSION}

The results of the investigations into the grain size distribution of the tetra carbides powder $\left(d_{10}=1.45 \mu \mathrm{m}\right.$, $d_{50}=3.11 \mu \mathrm{m}$ and $d_{90}=7.36 \mu \mathrm{m}$ ), and especially the values $d_{10}$ and $d_{90}$, allow us to calculate the filling ratio of the injection-moulded section $S_{\mathrm{W}}$ according to the following dependence $S_{\mathrm{W}}=2.56 /\left(\log (\mathrm{d} 90 / \mathrm{d} 10)\right.$. The $S_{\mathrm{W}}$ value calculated is 3.64 , which allows for the injection moulding of the powder examined. Powder with a $S_{\mathrm{W}}$ coefficient of 2 is the most recommended for injection moulding. It is not recommended to mould powder with a $S_{\mathrm{W}}$ coefficient of 7 with its powder grain size distribution characteristic being very narrow. The characteristic of the examined powder's grain size distribution is relatively broad, therefore, the pores forming between large grains may be filled by small particles. No grain size distributions tests and $S_{\mathrm{W}}$ coefficient calculations were made for the mixtures of powders manufactured by

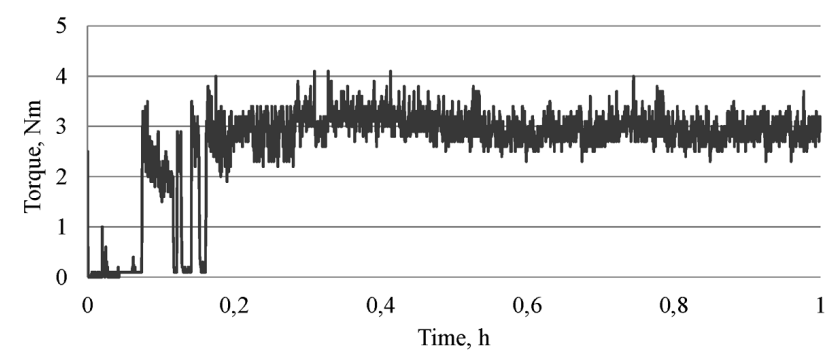

Figure 6: Torque measurements of feedstock based on PP and PW with $64 \%$ amounts of CC1 mixture carbides

Slika 6: Meritve navora mešanice, ki temeljijo na PP in PW s $64 \%$-nim deležem zmesi karbidov CC1
Baildonit, as such powders are prepared as a granulated product and mainly intended for pressing.

It was determined according to tests of the torque tested during the homogenisation of powder mixtures with a binder that, irrespective of the powders used, their maximum fraction should not exceed $60 \%$. The tested torque of stirrers is considerably decreased by adding stearic acid.

Figure 6 shows a torque chart for a mixture of $64 \%$ $\mathrm{CC} 1$ carbide with $13 \%$ of paraffin and polypropylene in volume. The mixture was produced at $170{ }^{\circ} \mathrm{C}$. The characteristic of the curve presenting the torque according to the feedstock mixing time is unstable, signifying an excessive fraction of carbide powders and inhomogeneous distribution of a binder in the matrix, despite a long homogenisation time. Besides, the curve does not show a falling tendency, despite long mixing, thus such a high content of powder cannot be used. In the case of a mixture with only $50 \%$ content of carbides, the torque of the stirrers falls below $1 \mathrm{Nm}$ after $20 \mathrm{~min}$, proving the low viscosity of the polymer and powder mixture. A smooth and falling characteristic of the curve signifies the mixture's high homogeneity.

A $50 \%$ content of carbides in the produced feedstock of the moulder or extruder ensures its low viscosity, but may cause numerous problems in the debinding of such a high fraction of a binder or may lead to the distortion of specimens during sintering as a result of high shrinkage of the sinter. Hence, a well-prepared feedstock should be characterised by a possibly high fraction of powder and relatively low viscosity enabling its formation. It has been concluded according to data from the literature and our own studies that the feedstock's viscosity is considerably reduced by applying a small amount of stearic acid as an active surfactant.

Table 3 shows the results of torque tests for the stirrers homogenising a polymer and powder slip for $1 \mathrm{~h}$, containing $60 \%$ of tetra carbides and a binder in the form of a paraffin (PW) and polypropylene (PP). The torque value is substantially decreased by using stearic acid (SA) covering the surface of the carbides (Table 3 ).

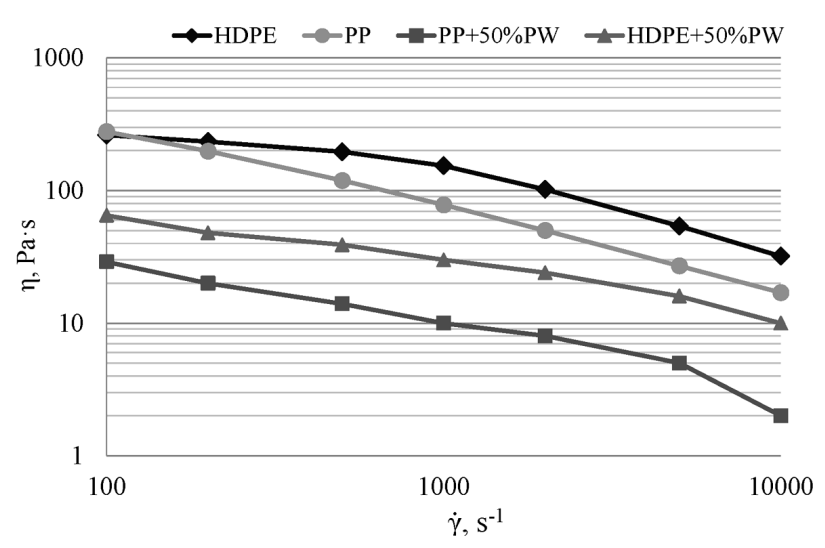

Figure 7: Influence of binder type on rheological behaviour at $170{ }^{\circ} \mathrm{C}$ Slika 7: Vpliv vrste veziva na reološko obnašanje pri $170{ }^{\circ} \mathrm{C}$ 


\section{MATERIALI IN TEHNOLOGIJE/MATERIALS AND TECHNOLOGY (1967-2017) - 50 LET/50 YEARS}

\section{K. GOEOMBEK et al.: RHEOLOGICAL PROPERTIES OF FEEDSTOCKS AND THE STRUCTURE ...}

A low torque value of mixtures containing polypropylene (PP) and paraffin (PW) corresponds to a low viscosity. The torque is only negligibly reduced by increasing the content of stearic acid from $4 \%$ to $8 \%$, hence its content in further investigations did not exceed $4 \%$.

Table 3: Torque measurements of feedstock based on PP. PW and SA with $60 \%$ amounts of TC mixture carbides covered by SA

Tabela 3: Meritve navora mešanice, ki temeljijo na PP, PW in SA s $60 \%$-nim deležem TC zmesi karbidov, ki jih zajema SA

\begin{tabular}{|c|c|c|c|}
\hline \multirow{2}{*}{ Time, min } & \multicolumn{3}{|c|}{ Torque, Nm } \\
\cline { 2 - 4 } & $0 \% \mathrm{SA}$ & $4 \% \mathrm{SA}$ & $8 \% \mathrm{SA}$ \\
\hline 5 & 12.20 & 2.20 & 1.80 \\
\hline 10 & 7.30 & 5.90 & 1.40 \\
\hline 15 & 5.50 & 1.80 & 1.30 \\
\hline 20 & 6.00 & 1.70 & 1.20 \\
\hline 25 & 5.20 & 2.10 & 1.20 \\
\hline 30 & 4.90 & 1.90 & 1.20 \\
\hline 35 & 5.50 & 1.80 & 1.10 \\
\hline 40 & 5.20 & 1.60 & 1.20 \\
\hline 45 & 4.90 & 1.60 & 1.10 \\
\hline 50 & 4.90 & 1.60 & 1.10 \\
\hline 55 & 5.50 & 1.50 & 1.00 \\
\hline 60 & 4.70 & 1.40 & 1.10 \\
\hline
\end{tabular}

The outcomes of the rheological tests indicate a smaller viscosity of a powder mixture with PP and PW in respect of a mixture containing High-Density Polyethylene (HDPE) instead of PP, and this is independent of the homogenisation rate. Viscosity is also considerably lowered by applying PW, as confirmed by the results of the rheological tests provided in Figure 7. In addition, paraffin allows us to use solvent debinding, expediting the rate of thermal debinding and this shortens the duration of the whole cycle. Figure 8 presents the effect of the fraction of carbides coated and uncoated with stearic acid on the viscosity of the polymer and powder mixture. Polypropylene and paraffin are the main binder components, regardless the content of stearic acid.

Stearic acid improves the wettability of metallic and ceramic powders by covering their oxided (polar) surface

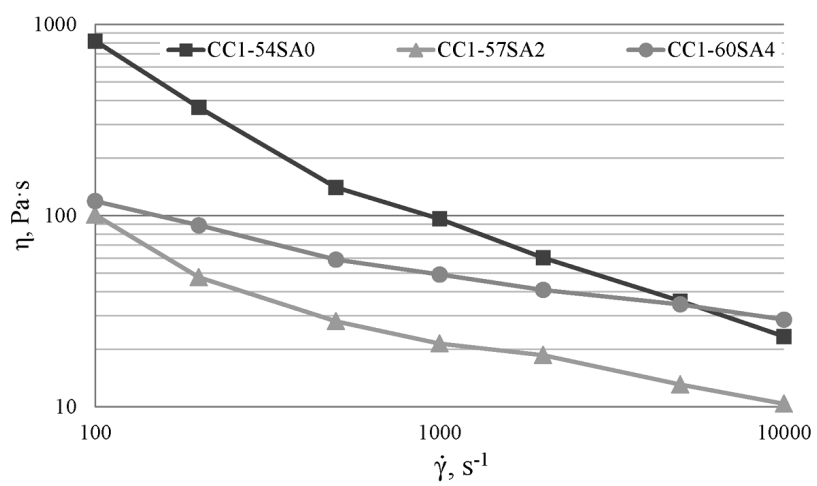

Figure 8: Influence of SA on rheological behaviour of binder and carbides CC1 type mixtures at $170{ }^{\circ} \mathrm{C}$

Slika 8: Vpliv SA na reološko obnašanje veziva in zmesi karbidov $\mathrm{CC} 1$ pri $170{ }^{\circ} \mathrm{C}$ that adsorbs the hydrophilic part of the chain as a result of the existing electrostatic forces between the powder and the wetting agent. The non-polar part of the chain should be mixed without limitations with other polymers present in the binder.

Apart from the decreasing viscosity, stearic acid acts as a lubricant in contact between the powder and the die surface or the surface of another particle. It also prevents powders from migrating during high-speed homogenisation. A process of migrating the powder inside the capillary or the destruction of the binder structure occurs most probably during the high-speed homogenisation of a mixture not containing stearic acid, presented in Figure 8. This is manifested by a strongly falling viscosity together with an increased homogenisation speed. The viscosity of mixtures containing stearic acid is not so much dependent on the homogenisation speed, hence the growing speed of homogenisation does not have such a strong effect on the structure of a homogenous mixture.

Considering the feedstock viscosity, the maximum applicable fraction of carbides uncoated with stearic acid is $50 \%$. If stearic acid is used for a mixture containing $50 \%$ of carbides, the viscosity is greatly reduced and a higher volume fraction of carbides can be obtained. The maximum volume fraction of powders applicable in a mixture for injection moulding could be determined by investigating the technological properties of the polymer and the powder mixtures containing binder-carbides.

A test in a capillary rheometer could not have been made due to the excessive viscosity of the mixture containing $68 \%$ of powder. Three polymer-powder mixtures are shown in the diagram. Two of them contain additionally SA, apart from the main binder components. It can be concluded by analysing the research outcomes that the content of stearic acid, similar to the tetra carbides, is strongly reducing the viscosity of the examined polymer-powder mixtures containing $\mathrm{CC} 1$ carbides. The mixture with the lowest content of powder and without SA possesses the highest viscosity. For the homogenisation speed of $5000 \mathrm{~s}^{-1}$ and $10000 \mathrm{~s}^{-1}$, the viscosity of

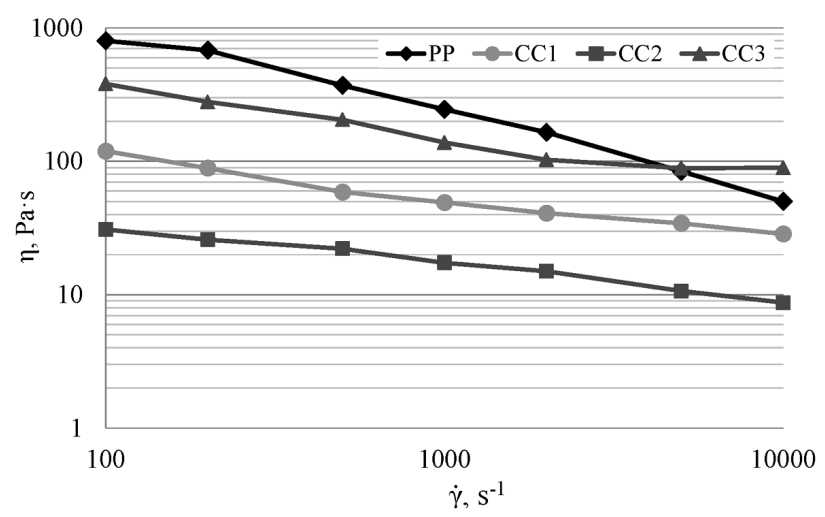

Figure 9: Influence of the type of carbides on rheological behaviour of the feedstock at $170{ }^{\circ} \mathrm{C}$

Slika 9: Vpliv vrste karbidov na reološko obnašanje mešanice pri $170{ }^{\circ} \mathrm{C}$ 


\section{MATERIALI IN TEHNOLOGIJE/MATERIALS AND TECHNOLOGY (1967-2017) - 50 LET/50 YEARS}

\section{K. GOŁOMBEK et al.: RHEOLOGICAL PROPERTIES OF FEEDSTOCKS AND THE STRUCTURE ...}

the CC154SA0 mixture is accordingly equal and lower than the viscosity of the CC160SA4 mixture. The CC157SA2 mixture has the lowest viscosity, irrespective the homogenisation speed. Figure 9 shows the results of the viscosity tests according to the type of powder used. Regardless of the powder used, the content of the binder was $40 \%$, including $4 \%$ of SA.

A mixture with tetra carbides powders applied has the highest viscosity. This is most likely connected with the fact that Baildonit's powder mixtures intended for pressing contain about $2 \%$ of volume fraction of lubricant, most often paraffin, additionally increasing the wettability and reducing the viscosity. Mixtures designed for the industrial manufacturing of sintered carbides possess a high homogeneity and lubricant are tightly covering the surface of carbides. It is thus easier to prepare a polymer powder slip for injection moulding and the slip itself has better properties. Regardless of the mixture type, the viscosity is lower than $1000 \mathrm{~Pa} \cdot \mathrm{s}$, hence each of the investigated mixtures is suitable for injection moulding. Figure $\mathbf{1 0}$ compares the results of the viscosity tests for a mixture with tetra carbides applied with pure polypropylene. The viscosity of polypropylene, often used for injection moulding, is higher than the homogenisation speed by $100 \mathrm{~s}^{-1}$ to $5000 \mathrm{~s}^{-1}$, which confirms the earlier conclusion that a mixture with tetra carbides is suitable for injection or extrusion moulding.

Figure 11 presents the diagrams of dependency between stress and homogenisation speed for CC1S60SA4 and CC260SA4 mixtures. The stress is growing as the homogenisation speed grows. Higher stresses are present in a CC1S60SA4 material due to its higher viscosity.

The binder's melting point and debinding temperature start tests were made to determine an injection temperature. An injection temperature of $170{ }^{\circ} \mathrm{C}$ was determined according to such measurements. The results of the binder's melting point and crystallisation temperature tests, determined with Differential Scanning Calorimetry (DSC), are shown in Table 4 . The melting point of polypropylene is $163{ }^{\circ} \mathrm{C}$; however, when mixed with

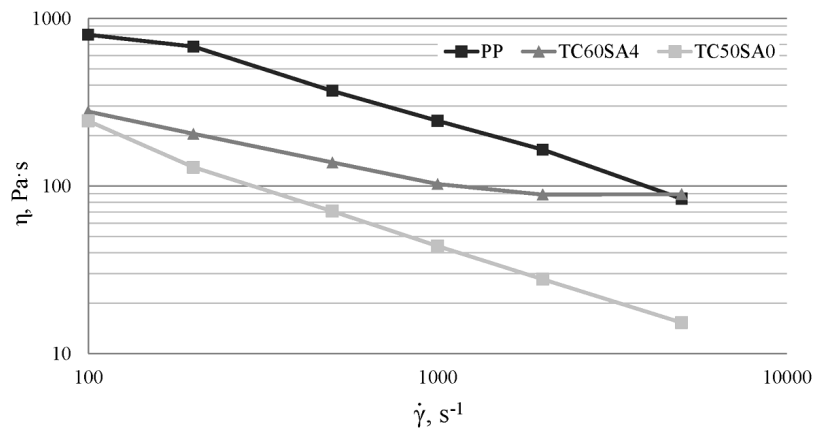

Figure 10: Comparison of feedstock viscosity including TC carbides with viscosity of polypropylene

Slika 10: Primerjava viskoznosti polnil za PIM, ki vključuje karbide $\mathrm{TC} \mathrm{z}$ viskoznostjo polipropilena

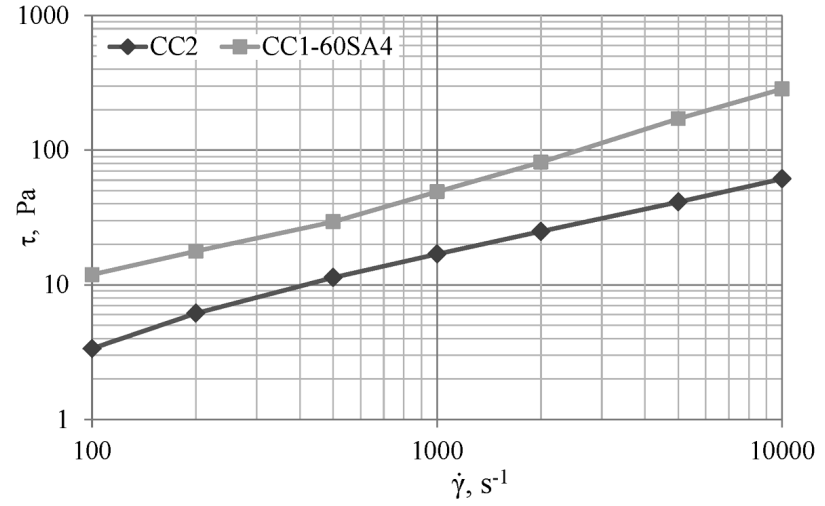

Figure 11: Flow curves of CC160SA4 and $\mathrm{CC} 2$ feedstock at $170{ }^{\circ} \mathrm{C}$ Slika 11: Krivulje tečenja za CC160SA4 in CC2 polnilo pri $170{ }^{\circ} \mathrm{C}$

paraffin in the same fraction, the melting point falls to $137^{\circ} \mathrm{C}$.

Table 4: Melting point and crystallization temperature of binder components and their mixture

Tabela 4: Tališče in temperatura kristalizacije komponent veziva in njihove zmesi

\begin{tabular}{|c|c|c|}
\hline Material & $\begin{array}{c}\text { Melting point } \\
\left({ }^{\circ} \mathrm{C}\right)\end{array}$ & $\begin{array}{c}\text { Crystallization } \\
\text { temperature }\left({ }^{\circ} \mathrm{C}\right)\end{array}$ \\
\hline HDPE & 130 & 61 \\
\hline PP & 163 & 108 \\
\hline PW & 58.3 & 47.5 \\
\hline SA & 73 & 62 \\
\hline $\mathrm{HDPE} / \mathrm{PW}$ & $t_{1}=57.8 ; t_{2}=127$ & $t_{1}=43 ; t_{2}=72$ \\
\hline $\mathrm{PP} / \mathrm{PW}$ & $t_{1}=56.6 ; t_{2}=137$ & $t_{1}=45 ; t_{2}=90$ \\
\hline
\end{tabular}

Thermogravimetric analysis (TGA) for the polymers used, ready binders and ready polymer-powder mixtures were carried out to determine the start temperature of the thermal debinding and to select its cycle preceding sintering. The test results are provided in Table 5. The volume fraction of paraffin (PW) versus the main binder of $50 \%$ was assumed. If the PW fraction is increased, the strength properties of the section moulded are deteriorated, while the increased fraction of PP or HDPE precludes the use of solvent debinding.

Table 5: Temperature of the start and finish of thermal debinding Tabela 5: Temperatura začetka in končanja toplotnega odstranjevanja veziva

\begin{tabular}{|c|c|c|}
\hline Polymer of mixture & $\begin{array}{c}\text { Temperature of } \\
\text { beginning of } \\
\text { thermal debinding } \\
\left({ }^{\circ} \mathrm{C}\right)\end{array}$ & $\begin{array}{c}\text { Temperature of } \\
\text { complete thermal } \\
\text { debinding }\left({ }^{\circ} \mathrm{C}\right)\end{array}$ \\
\hline HDPE & 378 & 503 \\
\hline PP & 320 & 480 \\
\hline PW & 198 & 278 \\
\hline SA & 204 & 286 \\
\hline HDPE/PW & 234 & 497 \\
\hline PP/PW & 215 & 446 \\
\hline
\end{tabular}

An injection temperature cannot be higher than its value, especially considering the beginning of thermal debinding temperature, which is $217^{\circ} \mathrm{C}$. The thermal 


\section{K. GOŁOMBEK et al.: RHEOLOGICAL PROPERTIES OF FEEDSTOCKS AND THE STRUCTURE ...}

debinding of paraffin, used as one of the binder components, may otherwise occur. The rate of mass loss changes at $287{ }^{\circ} \mathrm{C}$, signifying the end of the paraffin debinding. The binder is subject to complete thermal debinding at $444{ }^{\circ} \mathrm{C}$. The temperature of thermal debinding can be selected on the basis of thermogravimetric test results. Direct sintering is necessary due to the low properties of the sections after complete thermal debinding. High-temperature heaters often cannot be used for debinding due to degradation products deposited onto the heat chamber's surface. Debinding in a separate device should then be applied. The related necessity to transport the specimens after debinding into a high-temperature heater device forces us to use incomplete debinding, ensuring minimum mechanical properties, enabling the transport of the specimens. The maximum thermal debinding temperature should be about $420{ }^{\circ} \mathrm{C}$ when analysing the TGA curve.

A heating rate should be lowered at the temperature of $217{ }^{\circ} \mathrm{C}$ where the paraffin debinding starts, as sections' breaking may occur due to the growing pressure of gaseous products of debinding in pores.

The thermogravimetric tests of the polymer-powder CC260SA mixture were also performed. A thermal debinding cycle shown in Figure 12 was selected based on the results of the tests. The rate of heating was chosen experimentally.

The heating rate in the thermogravimetric tests was $5{ }^{\circ} \mathrm{C} / \mathrm{min}$. Material defects such as cracks may occur during fast heating within the range of the binder's thermal debinding temperature. This is caused by a

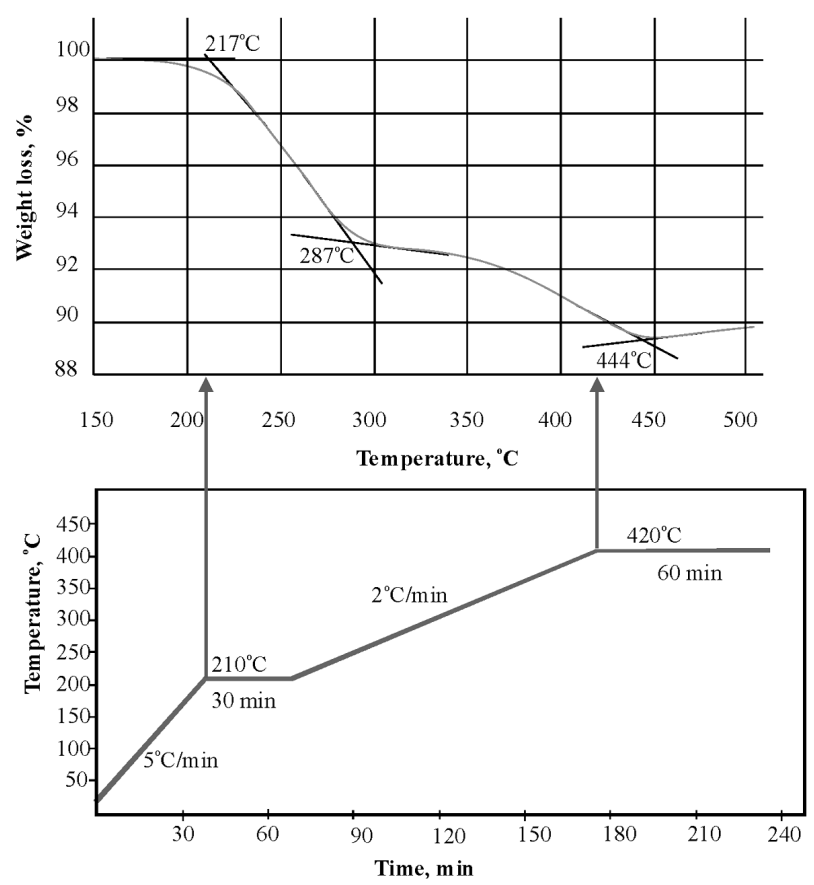

Figure 12: Thermal debinding cycle of CC1-60SA designed on the basis of TGA analysis

Slika 12: Cikel toplotnega odstranjevanja veziva pri CC160SA, zasnovan na podlagi TGA analize growth in the pressure of gaseous products formed as a result of the thermal debinding. The heating rate was lowered to $2{ }^{\circ} \mathrm{C} / \mathrm{min}$. for this reason, and an isothermal interval was additionally used at $200{ }^{\circ} \mathrm{C}$, i.e., the paraffin debinding start temperature. Another isothermal interval depends on several factors, such as the size of the heat chamber, the flow rate of the shielding gases or where a material must be transported into a chamber of another device for sintering. Where the transport of specimens is necessary, debinding should end at a temperature lower than this, resulting from a thermogravimetric curve. A thermal debinding cycle can be shortened by dissolving one of binder components, and no isothermal interval at $200{ }^{\circ} \mathrm{C}$, corresponding to paraffin debinding, is needed for solvent debinding. A heating rate of feedstock can be, therefore, increased to the debinding temperature of PP or HDPE. The binder components such as PP or HDPE do not undergo solvent debinding, and their role is to maintain the formed specimens' shape to the maximum temperature possible.

If the thermal debinding of a binder is carried out at a temperature corresponding to the final temperature of PP or HDPE debinding determined on the thermogravimetric curve, this is linked to the complete degradation of a binder binding the powder particles, hence, such a heat cycle can take place only in a high-temperature
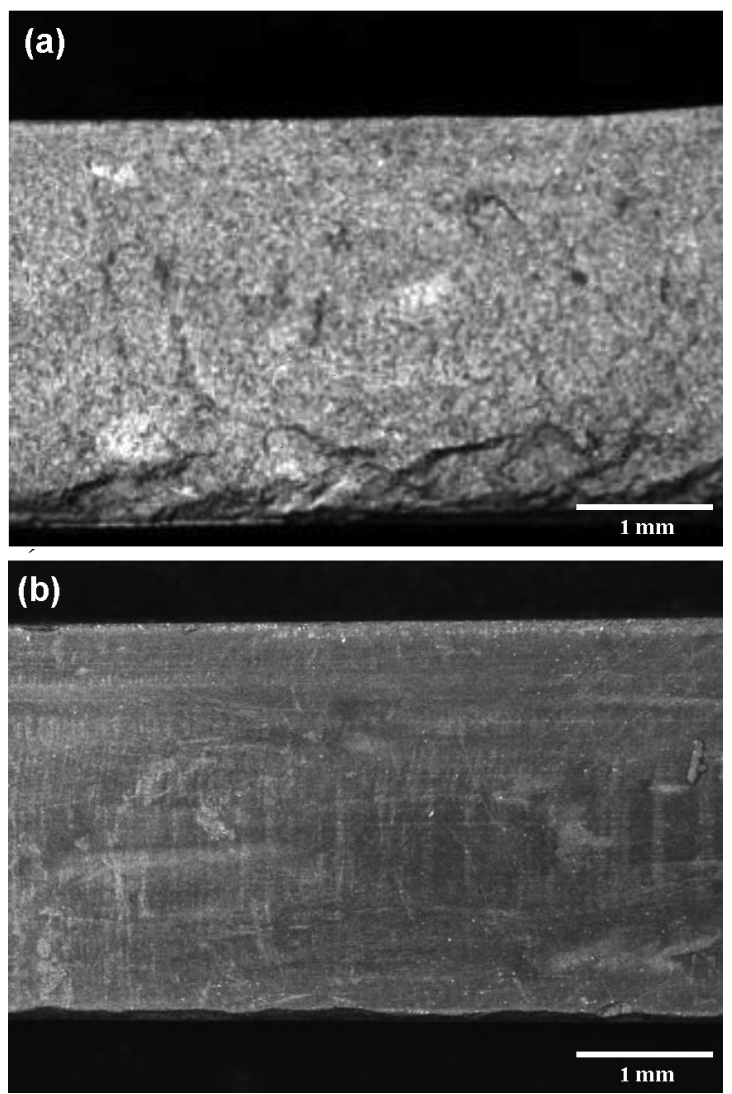

Figure 13: View of the fracture surface of injected CC2 materials: a), b)

Slika 13: Pogled na površini preloma injekcijsko brizganih CC2 materialov: a), b) 
K. GOŁOMBEK et al.: RHEOLOGICAL PROPERTIES OF FEEDSTOCKS AND THE STRUCTURE ...
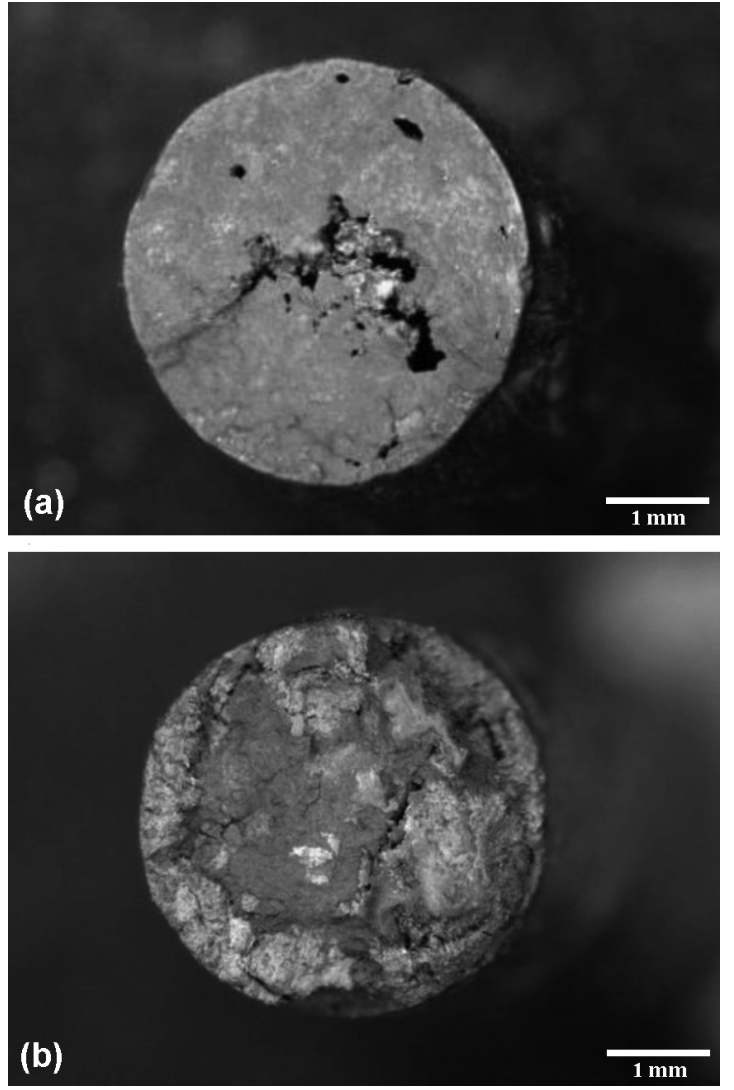

Figure 14: a) View of the fracture surface of CC160SA4 materials extruded at $140{ }^{\circ} \mathrm{C}$, b) view of the fracture surface of extruded CC157SA2 materials at $170{ }^{\circ} \mathrm{C}$

Slika14: Pogled na prelomni ploskvi ekstrudiranih materialov: a) $\mathrm{CC} 160 \mathrm{SA} 4$ pri $140{ }^{\circ} \mathrm{C}$, b) $\mathrm{CC} 157 \mathrm{SA} 2$ pri $170{ }^{\circ} \mathrm{C}$

furnace permitting direct sintering after finished debinding.

Otherwise, it is very difficult and dangerous for the materials manufactured to transport specimens from low-temperature heating devices, designed mainly for thermal debinding, to the chambers of high-temperature devices, due to their low mechanical strength.

Injection-moulded materials exhibit the highest bending strength due to a higher moulding pressure and fewer pores. Figure 13 shows the structure of the CC2S60SA4

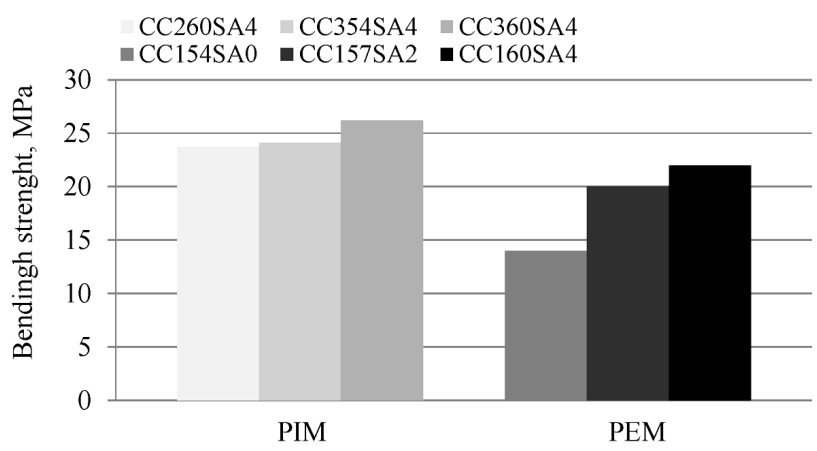

Figure 15: Bending strength of injected and extruded materials Slika 15: Upogibna trdnost injekcijsko brizganih in ekstrudiranih materialov material's fracture. No gas bubbles were identified in the material that may form during injection moulding and reduce the bending strength. Growing bending strength in the extruded specimens is linked to the presence of stearic acid covering the powder surface and enhancing the strength of the powder, i.e., binder bondage. The bending strength of the extruded specimens depends on the extrusion conditions. The fractures of the specimens extruded at $140{ }^{\circ} \mathrm{C}$ and $170{ }^{\circ} \mathrm{C}$ are given in Figures 14a and $\mathbf{1 4 b}$, respectively.

The results of the bending-strength tests from the injection moulded and extruded specimens are shown in Figure 15. The injection-moulded materials provide the highest resistance to bending due to the higher pressure and the formation of fewer pores.

\section{CONCLUSION}

The methods of injection moulding and extrusion of powders and sintering make it possible to fabricate small complex parts made of composite tool materials based on a cobalt or nickel-cobalt matrix, reinforced with hard carbide phases.

It was found based on the investigations conducted that the mixtures of carbide powders through injection extrusion or moulding can be produced by applying a binder in the form of paraffin or polyethylene. All the polymer-powder mixtures presented can be used for the injection moulding of powders or extrusion thereof and this is evidenced by the outcomes of the rheological tests presented. The fraction of powder in relation to powder in a slip can be increased by applying a surfactant such as stearic acid. Stearic acid is clearly reducing the viscosity of the investigated polymer-powder mixtures, hence its use is substantiated. The binder content in injection moulded or extruded materials should be as small as possible, enabling slip moulding only. Excessive binder content poses difficulties in degradation and causes a larger shrinkage and potential distortion in sintering. The results of the bending strength tests mainly depend on the conditions of moulding that should be selected so that the structure of the moulded specimens is uniform and does not exhibit any discontinuities. It is predicted that further investigations of such materials consisting of the selection of appropriate debinding and sintering conditions will make it possible to produce ready complex tool materials in the form of sintered carbides characterised by appropriate custom-made properties.

The application of the state-of-the-art powder moulding methods for producing composite tool materials reinforced with hard carbide phases is substantiated. The application of injection moulding or extrusion processes, opposite to casting processes and classical powder metallurgy, allows us to manufacture composite materials with complicated shapes and a developed geometry, including tool materials with a wide range of content of reinforcing 


\section{MATERIALI IN TEHNOLOGIJE/MATERIALS AND TECHNOLOGY (1967-2017) - 50 LET/50 YEARS}

\section{K. GOEOMBEK et al.: RHEOLOGICAL PROPERTIES OF FEEDSTOCKS AND THE STRUCTURE ...}

particles, without having to use additional procedures and sorting typical for casting materials.

\section{REFERENCES}

${ }^{1}$ G. Matula, L. A. Dobrzański, G. A. Herranz, A. Varez, B. Levenfeld, J. M. Torralba, Influence of binders on the structure and properties of high speed-steel HS6-5-2 type fabricated using pressureless forming and PIM methods, Materials Science Forum, 534-536 (2007) 1, 693-696, doi:10.4028/www.scientific.net/MSF.534-536.693

${ }^{2}$ G. Matula, L. A. Dobrzański, A. Varez, B. Levenfeld, J. M. Torralba, Comparison of structure and properties of the HS12-1-5-5 type high-speed steel fabricated using the pressureless forming and PIM methods, Journal of Materials Processing Technology, 162 (2005), 230-235, doi:10.1016/j.jmatprotec.2005.02.166

${ }^{3}$ V. Leschynsky, M. Ignatev, H. Wiśniewska-Weinert, J. Borowski, T. Rybak, I. Dobrovnik, Forging tools modification with graphene-like solid lubricant nanoparticles, Journal of Achievements in Materials and Manufacturing Engineering, 43 (2010), 341-348, jamme.acmsse. h2.pl/papers_vol43_1/43137.pdf

${ }^{4}$ H. Wiśniewska-Weinert, V. Leshchynsky, M. Ignatev, J. Borowski, T. Wiśniewski, Innovative technology for fabrication of antiwear layers for forging tools, Tribologia, 239 (2011) 5, 239-248, t.tribologia.eu/ trib/artykul/2015-06-23-Tribo-11v42n5_p239_248.pdf

${ }^{5}$ S. Zhao, X. Song, Ch. Wei, L. Zhang, X. Liu, J. Zhang, Effects of WC particle size on densification and properties of spark plasma sintered WC-Co cermet, International Journal of Refractory Metals and Hard Materials, 27 (2009) 6, 1014-1018, doi:10.1016/j.ijrmhm. 2009.07.017

${ }^{6}$ A. Eder, W. Lengauer, K. Dreyer, H. Van Den Berg, H.-W. Daub, D Kassel, Phase formation during sintering of functionally graded hardmetals, Plansee Seminar, 2005

${ }^{7}$ A. S. Bolokang, A comparison of the mechanically alloyed (V,W)C and $(\mathrm{V}, \mathrm{W}) \mathrm{C}-\mathrm{Co}$ powders, Journals of Alloys Compound, 477 (2009) 1-2, 905-908, doi:10.1016/j.jallcom.2008.11.038

${ }^{8}$ M. Rosso, Ceramic and metal matrix composites: Routes and properties, Journal of Materials Processing Technology, 175 (2006), 364-375, doi:10.1016/j.jmatprotec.2005.04.038

${ }^{9}$ W. Acchar, C. Zollfrank, P. Greil, Microstructure and mechanical properties of WC-Co reinforced with $\mathrm{NbC}$, Materials Research, 7 (2004) 3, 445-450, doi:10.1590/S1516-14392004000300012

${ }^{10}$ H. O. Andrén, Microstructure development during sintering and heat-treatment of cemented carbides and cermets, Materials Chemistry and Physics, 67 (2001), 209-213, doi:10.1016/S02540584(00)00441-7
${ }^{11}$ R. M. German and A. Bose, Injection Molding of Metals and Ceramics, MPIF, Princeton, NJ. 1997

${ }^{12}$ R. M German, Global research and development in powder injection moulding, Powder Injection Moulding International, 1 (2007) 2, 33-36

${ }^{13}$ F. Petzoldt, Metal injection moulding in Europe: ten facts that you need to know, Powder Injection Moulding International, 1 (2007) 2, 23-28

${ }^{14}$ H. Ye, X. Y. Liu, H. Hong, Fabrication of metal matrix composites by metal injection molding-A review, Journal of Materials Processing Technology, 200 (2008), 12-24, doi:10.1016/j.jmatprotec.2007. 10.066

${ }^{15}$ M. Wright, L. J. Hughes and S. H. Gressel, Rheological characterization of feedstocks for Metal Injection Molding, Journal of Materials Engineering and Performance, 3 (1994) 2, 300-306, doi:10.1007/BF02645856

${ }^{16}$ J. A. Moore, B. P. Jarding, B. K. Lograsso and I. E. Anderson, Atmosphere control during debinding of powder injection molded parts, Journal of Materials Engineering and Performance, 4 (1995) 3, 275-282, doi:10.1007/BF02649064

${ }^{17}$ T. Li, Q. Li, J. Y. H. Fuh, P. C. Yu, L. Lu, Two-material powder injection molding of functionally graded WC-Co components, International Journal of Refractory Metals and Hard Materials, 27 (2009), 95-100, doi:10.1016/j.ijrmhm.2008.04.005

${ }^{18}$ A. Simchi, F. Petzoldt, Cosintering of Powder Injection Molding parts made from ultrafine WC-Co and 316L stainless steel powders for fabrication of novel composite structures, Metallurgical and Materials Transactions A, 41A (2010), 233-241, doi:10.1007/ s11661-009-0045-5

${ }^{19}$ L. A. Dobrzański, B. Tomiczek, M. Pawlyta, M. Król, Aluminium $\mathrm{AlMg} 1 \mathrm{SiCu}$ matrix composite materials reinforced with halloysite particles, Archives of Metallurgy and Materials, (59) (2014), 335, doi:10.2478/amm-2014-0055

${ }^{20}$ M. Collin, S. Norgren, Hardness gradients in WC-Co created by local addition of $\mathrm{Cr}_{3} \mathrm{C}_{2}$, Proceedings of the $16^{\text {th }}$ International Plansee Seminar, Reutte, (2005), 277-241

${ }^{21}$ X. H. Qu, J. X. Gao, M. L. Qin, C. M. Lei, Application of a wax-based binder in PIM of WC-TiC-Co cemented carbides, International Journal of Refractory Metals and Hard Materials, 23 (2005), 273-277, doi:10.1016/j.ijrmhm.2005.04.006

${ }^{22}$ M. Bram, M. Bitzer, H. P. Buchkremer, D. Stover, Phase transformation behavior of Hot Isostatically Pressed NiTi-X ( $\mathrm{X}=\mathrm{Ag}, \mathrm{Nb}$, W) alloys for functional engineering applications, Journal of Materials Engineering and Performance, 21 (2012) 12, 2071-2712, doi:10.1007/s11665-012-0375-0 